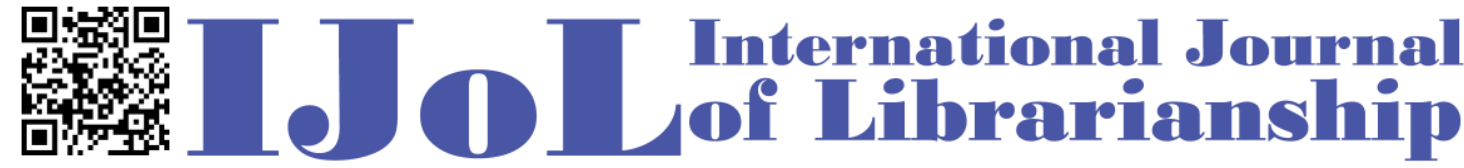

ISSN: 2474-3542 Journal homepage: http://journal.calaijol.org

\section{Chinese Academic Library Services: A Web Survey}

Guoying Liu

\begin{abstract}
:
Chinese students form a significant population on Canadian university campuses. Literature indicates that these students face various challenges when using library services to meet their information needs. Canadian academic libraries need to better understand this group's previous library experiences in China to help them address these challenges. A survey was conducted on the main library websites of all thirty-nine Chinese universities of the Project 985, a project initiated by Chinese government to found world class universities in China. It reveals that certain services reported as challenges for Chinese students by previous studies, such as: interlibrary loan, document delivery, reference services, and library instructions are popular in Chinese academic libraries; however, subject services, data services, and some other services are not as well established compared to their counterparts in Canada.
\end{abstract}

To cite this article:

Liu, G. (2016). Chinese academic library services: a web survey. International Journal of Librarianship, 1(1), 38-54. https://doi.org/10.23974/ijol.2016.vol1.1.14

To submit your article to this journal:

Go to http://ojs.calaijol.org/index.php/ijol/about/submissions 


\title{
Chinese Academic Library Services: A Web Survey
}

\author{
Guoying Liu \\ Leddy Library, University of Windsor, Windsor, Ontario, Canada
}

\begin{abstract}
Chinese students form a significant population on Canadian university campuses. Literature indicates that these students face various challenges when using library services to meet their information needs. Canadian academic libraries need to better understand this group's previous library experiences in China to help them address these challenges. A survey was conducted on the main library websites of all thirty-nine Chinese universities of the Project 985, a project initiated by Chinese government to establish world class universities in China. It reveals that certain services reported as challenges for Chinese students by previous studies, such as: interlibrary loan, document delivery, reference services, and library instructions are popular in Chinese academic libraries; however, subject services, data services, and some other services are not as well established compared to their counterparts in Canada.
\end{abstract}

Keywords: Academic Libraries, International Students, Library Services, Canada, China

\section{INTRODUCTION}

The number of international students has been increasing significantly in the past twenty years. In 1996, there were 71,054 international students studying in Canada (Citizenship and Immigration Canada [CIC], 2006); and the number went up to 336,497 by the end of 2014 (CIC, 2015). The impact of international students on Canadian higher education is huge. According to the Canadian Bureau for International Education (2016), in the 2012-2013 academic year, 11\% of students registered in the postsecondary institutes in Canada were international. Among the origin countries of these students, China has ranked at the top since 2002. In 2014, the number of students from China reached 110,918 , representing nearly one third of the total international student population in Canada. (CIC, 2015)

Identifying strategies to serve this group of students has been a challenge to Canadian academic libraries. What are Chinese students' experiences and perceptions of academic libraries prior to their arrival to Canada? What services are offered or not offered by Chinese libraries compared to Canadian ones? This paper aims to answer these questions to obtain an overall understanding of the services provided by Chinese university libraries from the perspective of a Canadian academic librarian.

A web survey was conducted exploring the library services currently provided by the Project 985 universities in China. Project 985 is initiated in 1998 by the Chinese government aiming to establish a handful of world class universities in China. Till 2011, thirty-nine institutions in total are 
sponsored by Project 985 and no more institutions will be added into this group (Ministry of Education of the People's Republic of China, 2011). The results of this investigation will provide academic librarians with general knowledge of the availability and development of academic library services in China. It will also lead to a better understanding of the experiences, perceptions and expectations of Chinese students about the library. Finally, it will help Canadian librarians provide appropriate services and effective support to this group of students.

\section{LITERATURE REVIEW}

Related literature can be divided into two categories: the first includes studies on international students and the second is on Chinese academic libraries. The former tends to be case studies from students' perspective. Some students may have attended Western universities previously or have already established themselves in the host country prior to their participation in these studies. Furthermore, many studies rely on students' self-reports or their memories, particularly with regard to their previous experience in China. Research shows that students tend to be overconfident with their library knowledge or skills (Howze \& Moore, 2003; Kim \& Shumaker, 2015), not to say their recall over past experiences could be inaccurate. The composition of international students has been changing quickly over the past two years, and even students from China may have different previous library experiences and exposure to Western cultures. Previous studies do not generate a full and accurate picture of the experiences and perceptions of current Chinese students with academic libraries in China.

Studies in the second category investigate different aspects of Chinese academic libraries and reveal certain issues and situations. All of them noted the rapid development of these libraries. More research is needed for Canadian libraries and librarians to obtain a thorough understanding of the academic library services in China to comprehend Chinese students' experiences, perceptions and expectations with library.

\section{Research on International Students in Canada, the US and Other Western Countries}

Various studies have been conducted on the information needs of international students and the academic library services available in Canada, the United States and other Western countries. It is well documented that international students face unique challenges using libraries to meet their academic needs. This includes unfamiliarity with academic library systems, lack of understanding of the professional role of librarians or unawareness of many library services or resources along with language and cultural barriers. (Datig, 2014; Jackson, 2005; Liao, Finn, \& Lu, 2007; Liu \& Winn, 2009). Jackson (2005) points out that international students are not aware of certain library services, including: interlibrary loan (ILL), individual assistance with a subject librarian and chat reference. A study comparing the library use of international students and American students reveals that international students are less aware of ILL, online database searching, in-person consultation with a librarian and library instruction sessions (Liao et al., 2007). The authors argue that the difference between international students and American students may be due to the lack of such services in their home countries. Datig (2014) reveals that there is a lack of understanding among international students about the professional role of librarians.

Some studies focus on Chinese students rather than treat international students from different countries as a homogeneous group. Wang's (2006) research reveals that various services are underused by Chinese students in New Zealand, including: library instruction, reference services and individual appointment with subject librarians. Morrissey and Given (2006), studied the library usage and information literacy skills of Chinese graduate students in Canada. They conclude that 
most Chinese students rely heavily on commercial search engines to meet their information needs and tend not to evaluate the quality of resources. Another observation is that most Chinese students do not understand the role of librarians. Their previous library experiences in China consisted of the use of closed library stacks and card catalogues. Liu and Winn's (2009) investigation at another Canadian institution finds that Chinese students perceive the Chinese academic library as a place to study, borrow books or access electronic resources, and the role of Chinese librarians as maintaining and circulating books. They do not know about reference services. When these students study in Canada, they are unaware of many library services, including: ILL, multimedia center, data services, and the research and writing guides available on the library website. They also lack understanding of legal and ethical issues regarding information access and use.

Shao, Scherlen, Johnson, $\mathrm{Xu}$, and $\mathrm{Hu}$ (2013) surveyed Chinese students' satisfaction with the American library experience when they returned from the US to China. The paper indicates that the students like to study in American libraries but are often unaware of the reference librarians' role. Zhao and Mawhinney (2015) compared the information literacy challenges encountered by native Chinese speaking students and native English speaking students at a large Canadian university. It revealed that Chinese students face more challenges searching for, evaluating and citing information. "[Their] lack of knowledge of basic library resources and services and evaluating sources remained challenging for" these students (p. 722).

\section{Research on Chinese Academic Libraries}

Many previous studies concur that underdeveloped user services and a shortage of qualified librarians are longstanding problems in Chinese academic libraries (Liao, 2004; Shen, 2006; Xie \& Sun, 2015). Liao (2004) examined the root cause for the underdevelopment of services for users in Chinese academic libraries from a historical perspective. The author argues that user services are still a low priority in academic libraries in China although collection development, space expansion and information technology adoption have significantly improved since 1979. Through a comparison between Chinese and American librarianship, Shen (2006) concludes that "Chinese librarianship faces great challenges in the librarian recruitment and education and with the library system itself" (p. 89) due to social, cultural, economic and historical reasons. Employment as a librarian "confers low social status and people do not see librarianship as a profession enriched with knowledge and information skills" (p.92). In their survey conducted at a comprehensive Chinese university, Xie and Sun (2015) find that library resources and reference services have improved but the reference services are under-used by students and the services to students still need improvement.

Two web surveys have been conducted examining reference services and subject services offered by Chinese academic libraries. Wang, Niu, \& Hubbard (2004) investigated reference services on the library websites of 95 Project 211 institutions in China. Project 211 is a project initiated in 1995 by the Chinese government aiming to strengthen about 100 high level universities and key subjects for the $21^{\text {st }}$ century (Ministry of Education of the People's Republic of China, 2008). Wang et al.'s (2004) survey reveals that the homepages of 90 universities among the 95 Project 211 institutions were accessible and they all have reference librarians available although some schools merely provided an email address on the website. About a quarter of the libraries do not mention any user education probably because "most Chinese regard the library as a place to read and study, but not to ask" (p. 109). Tang and Xia (2010) examined subject services through a survey of the library websites of thirty top universities in China. They conclude that subject services are not yet popular in Chinese academic libraries; and both qualifications of the subject librarians and the scope of subject services are not as advanced as in the libraries in the US and the UK. 
Johnson, Shi, \& Shao (2010) compared the library service model between Fudan University in China and Appalachian State University in the US. The results indicate that: compared with Appalachian, Fudan does not offer one-on-one consultation with a librarian, 24-hour access, an assistive technology room, equipment checkout and service to distance learning students. The user guides and tutorials are still being tested at Fudan while they have been well established at Appalachian. In addition, Fudan does not provide off-campus access to most students. On the other hand, Fudan offers the services of novelty search and reports on citation and impact analysis of individual faculty research which do not exist in the American library. The authors argue that both services could be problematic. Fudan is a top Chinese university located in Shanghai, the largest city in China. The findings cannot be generalized to other Chinese higher education institutions.

All these papers note the rapid development of Chinese library systems and services since the 1980s. According to Guo, Huang, \& Lu (2014), China Academic Library and Information System (CALIS) launched a subject librarian training program to "cultivate a group of subject librarians with practical abilities and innovative spirit for Chinese university libraries and hence promote the development of librarianship in China" (p.43) in 2010. Has this kind of effort changed Chinese academic library services significantly? More research is needed to gain a thorough understanding of the current status of the services and systems in Chinese academic libraries, and to enable librarians in Canada to provide adequate services to the growing group of Chinese students on campus.

\section{METHOD}

A survey was conducted examining the content on the main library websites of the Project 985 universities in China. According to the Ministry of Education of the People's Republic of China (2015), there are 2,529 regular higher education institutions (HEIs), and an additional 1,094 adult and other non-government HEIs in China. It is too time consuming to examine all institutions. Project 985 universities represent the highest level of Chinese higher education. Study on these universities will provide an understanding on the library services offered in these institutions as well as an indication on the future direction of the services offered by all Chinese academic libraries.

The Appendix lists the thirty-nine Project 985 institutions and the URLs of their main library websites.

All data were collected between March 18-May 30, 2016. Spreadsheets were used to record the data gathered.

A pre-survey of Peking University Library was used to determine the categories and columns for data recording. Peking University Library is one of the earliest modern libraries in China. Currently, it hosts the administration centers or secretariats of CALIS, the China Academic Social Sciences and Humanities Library, the Digital Resource Acquisition Alliance of Chinese Academic Libraries, the Ministry of Education Higher Education Institution Library and Information Work Guidance Committee, and the Society for Academic Library, Library Society of China. (Peking University Library, n. d.) It is a leader among Chinese academic libraries.

Based on the pre-survey, five spreadsheets were created using Excel for the following categories: General Information; Access Services; Systems and Search Interfaces; Reference, Instruction and Subject Services; and Other Services. Several columns are named to record more detailed information under each category. A new column was added to the spreadsheet for any services or resources that were not originally included during the examination of other libraries. Special attention was paid to library hours, open stacks, reference services, subject services, and other 
issues reported in previous research. Library systems, search interfaces and innovative services were also examined. Since different Chinese terms are often used to describe the same or similar services in Chinese libraries (Li \& Yang, 2016; Su, 2016; Yao et al., 2015), a thorough examination of all possible terms or names of services and resources was conducted in order to ensure the accuracy and completeness of the data collected. When the author was uncertain about the meaning of a specific service or term on the webpage of a library website, or unclear about its status, other sources were consulted, including: other webpages or documents on the same site, other library websites, or publications on related topics.

During the examination of the websites, the author encountered various issues. Dalian University of Technology has a new website in beta. In this case, both the current and new websites were examined. Some library homepages or other webpages could not be opened initially. The author made multiple attempts to open them and in the end all library homepages were opened and examined (although some pages or services not accessible). Furthermore, sometimes the information listed in different places of a website conflicted with each other. For example, on the Southeast University Library website, the webpage Library Circulation Policy states that all faculty and students can borrow up to thirty items (the publication date is 2009-08-10), while the library education video for freshmen says faculty and graduate students can borrow up to ninteen items and undergraduate can only borrow nine items (no date indicated).

\section{RESULTS AND DISCUSSION}

\section{General Information}

General information includes: availability of the library links on the university homepages, English version of the library websites, annual reports, library communications and staff contact information. The survey finds that some libraries offer degree programs or host research institutes in the library and information studies in addition to regular library services. This information is recorded as well.

\section{Library links on the university homepages}

Nearly half of the institutions do not have a library link on their homepages. Many library links are hard to find; and it often takes multiple clicks to open library websites. For example, on the homepage of the Beijing Institute of Technology, users need to click on the About the University link, then choose Administrative Organizations, and then find the Library on the list of thirty-two Administrative Units which includes: Party Committee of Institution, Development and Planning, Students, Graduate Students, Human Resources, Finances, and Alumni. The library link being hidden among many administrative units may speak up a bit about the academic status of libraries in these universities.

\section{English version of the library websites}

About $60 \%$ of the libraries have an English version of their websites. Among them, two are not accessible; and one is in beta. Most English sites contain much less content than their Chinese versions. The English website may help students become familiar with library terminologies in English when they study in China. 


\section{Annual reports and library communications}

Only six libraries have their annual reports, budget information, or merely library collection usage statistics available online. It is also found that nine libraries edit and publish library communications or newsletters regularly on their websites. These documents would help users know more about the libraries.

\section{Staff contact}

Unlike their counterparts in North America, Chinese libraries rarely publish their staff directories online. Xiamen University Library is the only one that posted a long list of names, telephone numbers, email addresses, departments, and the supervisor of individual library staff in charge of each service or area available in a staff directory. Although it does not appear to include all library employees, it is the most complete list among all the libraries examined in this paper. On other libraries' websites, the contact information for certain services or staff is often posted on the Contact Us, Organization Structures or subject services page if available.

Twenty-four libraries have subject liaisons for certain faculties or departments. The name, telephone and email of the subject librarians are often posted on the service contact page or individual subject pages if available. The number of subject librarians are limited for many libraries, so the total number of librarians' names available online is quite small. For example, Xian Jiaotong University only lists eight liaison librarians' surnames.

Among the libraries that do not have subject liaisons, eight published a handful of individuals' names, telephone and/or email for the departments or public services. The remaining seven libraries only posted the telephone and/or email of some departments or service areas on their websites without any library staff name. Not knowing the librarians who provide certain services may discourage students from seeking help from librarians, being aware of or taking full advantage of their services.

\section{Library degree programs and research institutes}

The survey reveals that nine libraries offer Master's degree programs in library and information studies in addition to providing services to faculty and students. Two other libraries host library and information research institutes. There is no detailed information on how these programs and institutes are operated within the libraries. On one hand, this may help address the shortage of qualified librarians in Chinese libraries and promote the librarians' research in the field. On the other hand, it may affect the regular services provided to students at these universities. For instance, Beihang University has 80 employees in in the Library (Beihang University Library, 2016) who serve about 30,000 students and 3,800 faculty members at the University's thirty schools (Beihang University, 2016). The Library has been recruiting and teaching master's students for its two-year master's degree program in information science since 2007.

In summary, most Chinese libraries do not publish their annual reports and staff directories online. This may indicate that Chinese academic libraries are less open and interactive with their patrons compared to Canadian libraries. In addition, different from the practice in Canada, quite a few of Chinese academic libraries also offer master's degree education programs or research institutes in library and related fields. 


\section{Access Services}

This section covers: library hours, seating, study rooms, circulation policies, ILL and document delivery, open stacks and course reserves.

\section{Library hours}

This survey finds that the hours for opening and self-study areas are usually different from other services, such as: borrowing, card services, and reading rooms. During the academic semester, typical library hours for opening and self-study areas are Monday - Sunday, 8am-10pm and it is shorter on weekends for some libraries. The hours may be a bit longer during exam period. For example, Tsinghua University Library extends their hours for a half hour per day during exams. None of the libraries are open for 24 hours anytime of the year. It was also found that three university libraries close on Saturday evenings; and another three libraries have one weekday afternoon closure every week.

Many other areas have shorter hours, such as: circulation, library card services, reading rooms, ILL, document delivery and reference services. Close to $90 \%$ of the libraries have lunch breaks for some of these services. For example, at the Hunan University Library, the hours for the Basic Stacks Room and the Borrow and Return Desk on the third floor are Monday-Friday 8am-11:45am, 2:30pm-10:30pm; Saturday and Sunday: $8 \mathrm{am}-11: 45 \mathrm{am}, 2: 30 \mathrm{pm}-10: 30 \mathrm{pm}$. The two hours and forty-five minutes' service stoppage in the middle of everyday may discourage some students from using the services.

\section{Seats and study rooms}

In the About the Library section, many sites report the number of seats available for students to study or read in the library, ranging from a few hundred to over 10,000 seats. A few libraries, such as Xiamen University and China Agricultural University provide an online seat booking system for students to check and book seats ahead of time. Besides the seats in self-study areas, about half of the libraries indicate that they provide individual or group study rooms for students to use. Apparently, it is a priority for Chinese libraries to be a good study place for students.

\section{Circulation policies, ILL and document delivery}

Twelve libraries have the same borrowing privileges for all students, faculty and staff. Two of them have no limit for the number of items that can be borrowed by all campus users. Another twent-six libraries have different maximums based on the borrower's status as an undergraduate student, graduate student or faculty member. The last one has conflicted information regarding of this.

Although borrowing privileges vary among the libraries, the majority provide renewal services and two-third of them have a request service for all users.

Thirty-four institutions offer ILL and document delivery services.

\section{Open stacks and course reserves}

Open stacks are very common among surveyed libraries. Only seventeen libraries indicate that they still have closed stacks in some areas, usually special collections.

Twelve libraries have information about reference books in Course Reserves or webpages that are searchable by course name/code or instructor. It is hard to tell how the service is used by instructors and students. No matter what, course reserve is still under-developed in Chinese academic libraries. 
This section indicates that ILL, document delivery, requests and open stacks reported as challenges to international students in literature have become common in Chinese academic libraries. However, there are still gaps with regard to course reserves and the length and continuity of library hours for various services between libraries in China and Canada.

\section{Systems and Search Interfaces}

This section includes Open Public Access Catalogues (OPACs), Integrated Library Systems (ILSs), discovery layers, databases, e-journals, copyright notices and subject pages, off-campus access, $\mathrm{Wi}-\mathrm{Fi}$, and mobile services.

\section{OPACs and ILSs}

All libraries have an OPAC search interface for the library collections empowered by an ILS on their homepage. Figure 1 shows that nearly half of the ILSs are imported from foreign countries and while the others are developed domestically (including one homegrown system).

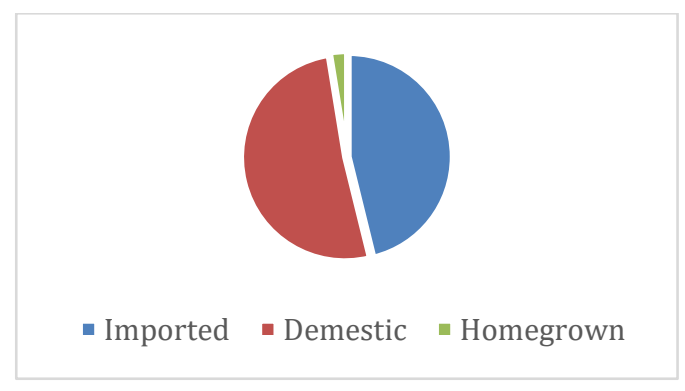

Figure 1. Types of ILSs

The breakdown for the imported systems is: Aleph 8, Millennium 5, Unicorn 4, and Horizon 1. See Figure 2.

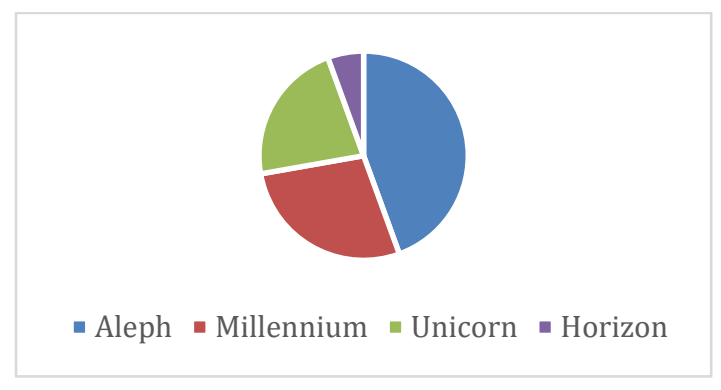

Figure 2. Imported ILS Products

Huiwen, Tuchang, ILAS, ADLIB and MELNETS are domestic products implemented in the libararies among which Huiwen is the most popular product.

All libraries allow patrons to log in to their accounts, view their circulation information, make requests, or recommend resources for purchase. 
It appears that none of the libraries has adopted the Unified Resource Management system or Library Services Platform that emerged in recent years in Western libraries. Nonetheless, students at these universities may be familiar with the interface and functionality of OPACs.

\section{Discovery layers}

Thirty-four institutions have implemented discovery layers for their resources. Another university, the South China University of Technology had trial subscriptions with Summon and EBSCO Discovery Service (EDS). Its website indicates that the EDS trial expired on June 20, 2015.

Figure 3 shows that among the discovery layer products adopted by the thirty-four libraries, fifteen are Summon, ten Primo Central and nine EDS. These are popular products in Canada as well. It may help Chinese students become familiar with the one-stop search interface before they study abroad.

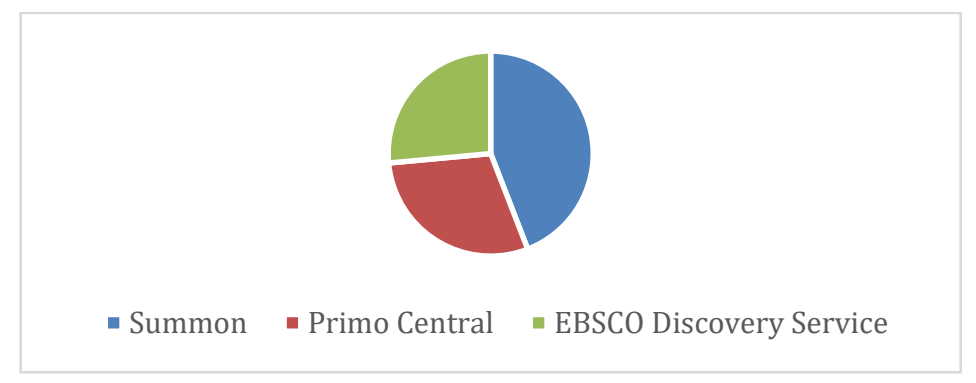

Figure 3. Discovery Layer Products

These discovery interfaces often have a localized Chinese name and are in the main search box on the library homepage. Figure 4 is a screenshot of the main search box on the Peking University Library homepage. The first tab is "Wei Ming Xue Shu Sou Suo" [Wei Ming Scholarly Search], the localized discovery layer powered by Summon. The other tabs are library catalogue, databases and e-Journals.

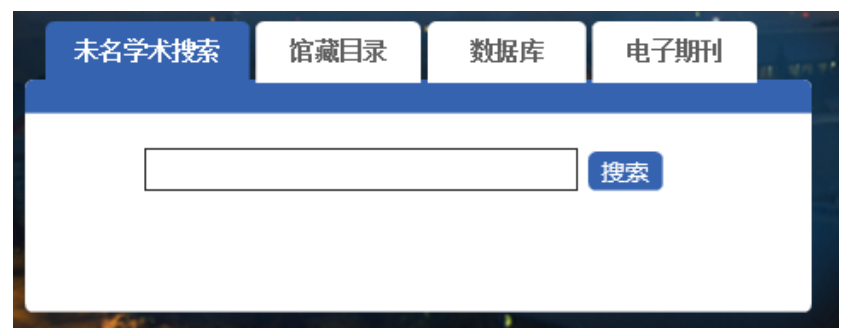

Figure 4. Screenshot of the Search Box on the Peking University Library Homepage

Many libraries have a Chinese resource search interface in addition to the discovery layer, which is different from Canadian libraries. Figure 5 shows the main search box on the homepage of the Sun Yat-sen University Libraries. The first tab is the "Zhi Hui Sou Suo" [Smart Search]. There are two search buttons on the bottom right of the box: one is Chinese search and the other non-Chinese search. When the Chinese search button is clicked, a login page for Chaoxing discovery system will pop up from which users can search for Chinese resources in Chaoxing. Whereas the nonChinese discovery button will take users to a results page powered by EDS. 


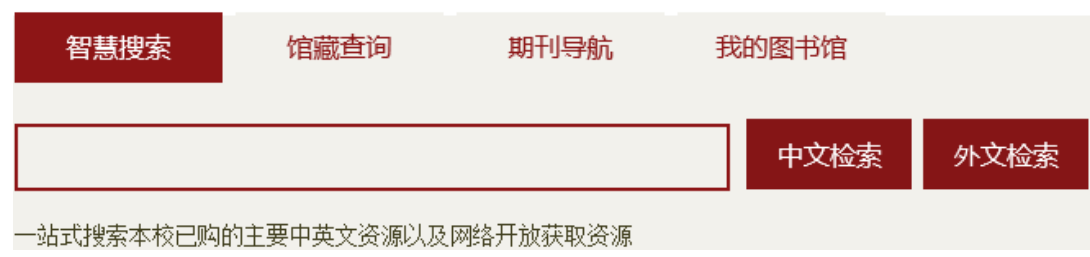

Figure 5. Screenshot of the Search Box on the Sun Yat-Sen University Libraries Homepage

Over $70 \%$ of the libraries have Chaoxing search boxes on their library websites. Unlike those discovery layer products, the Chaoxing search interface is usually IP protected. Users must log in with a valid account if they want to search the resources off campus. In addition to Chaoxing, eDu and Duxiu are adopted by a few libraries as well. They usually supplement Chaoxing for Chinese resource discovery in these universities.

\section{Databases, copyright notices, journal lists and subject pages}

All libraries list database resources by type, language, or subject. Most of them allow users to search or browse databases by title, subject, type, or language. Half of the libraries post copyright notices for database use.

Almost all libraries have journal lists for users to search or browse journal titles.

Over $60 \%$ of the libraries have subject services; however less than half have created subject guides introducing resources or services relevant to specific subjects. Most of the subject guides are built on LibGuides; and many of them are still under construction. Another issue is that the contents of many guides are not up-to-date. Take the Shangdong University Library as an example, only six subject guides are available on its website. Most of the guides were last updated between December 2013 - December 2014, which is about two to three years ago.

\section{Off-campus access, Wi-Fi, mobile services}

Thirty-five libraries offer off-campus access to their electronic resources and other services. One library is currently testing off-campus access through VPN. VPN is the method commonly adopted by most libraries. A couple of them also implemented proxy servers. Among the libraries providing off-campus access, only twenty-five provide the service to both faculty and students, while the rest only allow faculty or PhD students access to their resources off campus. See Figure 6.

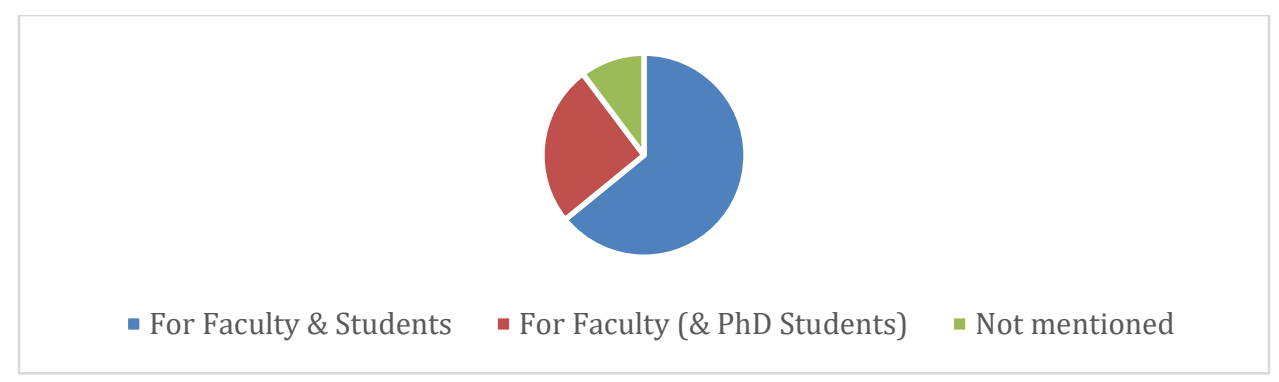

Figure 6. Off-Campus Access

For the libraries providing off-campus access to students, some offer this service to full time students only rather than the entire student population. For example, Fudan University clearly states that off-campus access is only for faculty, graduate students, and undergraduate students registered in degree programs. 
Fees or other restrictions associated with off-campus access service are mentioned by six libraries. Three post the fees that users are required to pay for. One states that a user can only use this service up to four hours per day. Two libraries indicate that this service opens to students only during the summer or winter vacations.

Figure 7 shows that over half of the libraries provide Wi-Fi throughout the library buildings. About one third do not mention such service on their websites.

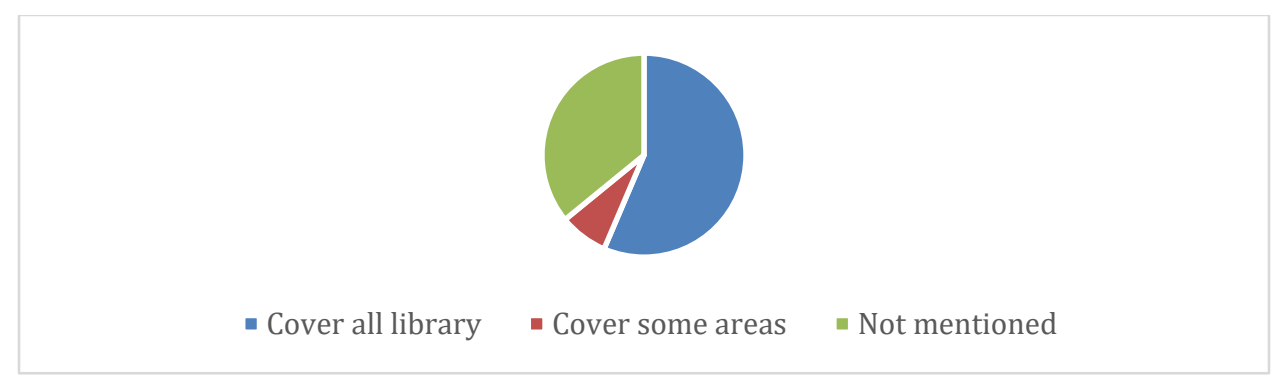

Figure 7. Wi-Fi in the Libraries

Regarding mobile services, over $80 \%$ of the libraries have developed mobile libraries or apps for many library functions, such as: library catalogue, e-reserves, and full-text readings.

\section{Self-services and online thesis/dissertation submission}

One third of the libraries have installed self-borrow/return machines. Another library is currently implementing such service. This service may help ease the limitations of circulation desk hours for students to borrow or return books. See Figure 8.

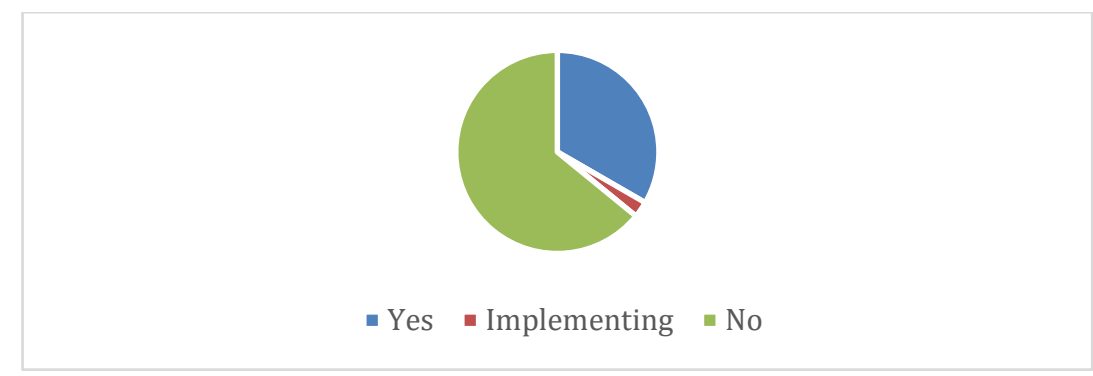

Figure 8. Self-Borrow/Return Machines

Nearly two third of the libraries offer users self-services for print, photocopy and scanning. Among those that do not have these services, over $60 \%$ indicate that they have print, photocopy, and scanning service operated by staff for students.

About three quarters of the libraries have implemented a system for students to submit their theses or dissertations online.

In summary, this section reveals that the following services are common in Chinese libraries surveyed: OPAC, online databases and other electronic resources, discovery search interfaces and mobile services. However, off-campus access to online resources is still not available to all students. 


\section{Reference, Instruction and Subject Services}

This section includes: reference and subject services, library instruction and credit courses.

\section{Reference services}

Reference services are provided by most libraries. However, five universities do not offer any type of reference services.

Among the libraries that have reference services, the majority provide two or more types available to their patrons. Figure 9 shows that in-person, virtual, telephone and email reference are almost equally adopted by these libraries; and each of them have been implemented by about half of the libraries.

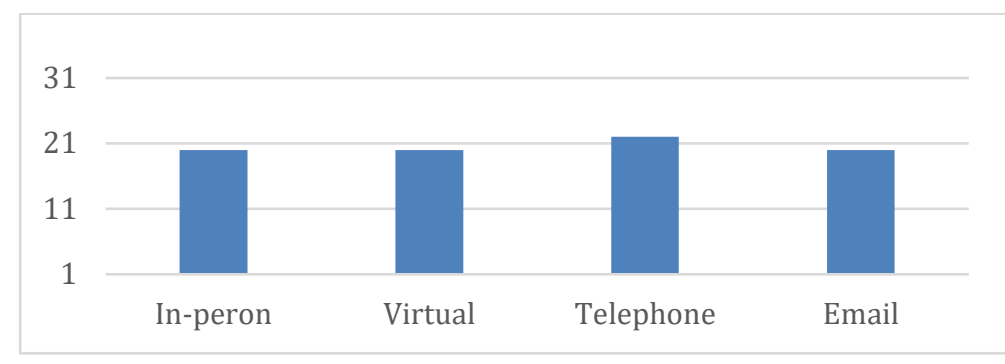

Figure 9. Categories of Reference Services

Other related services such as: FAQ, Online Bulletin and Feedback, Library Weibo and Wechat, University Librarian (UL)'s Email Box and Meet with UL are offered in many libraries as well. See Figure 10.

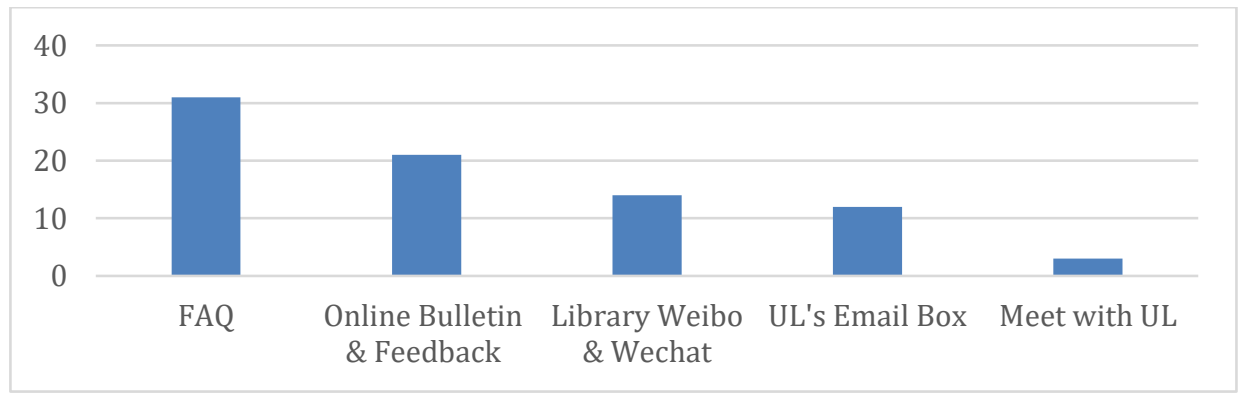

Figure 10. Other Services

\section{Library instruction and courses}

All libraries provide certain types of user training or education, including: freshmen instruction, library tours, introduction to library resources and search techniques and academic writing.

Over two thirds of the libraries provide online tutorials or library instruction via PowerPoint, pdf or videos available on the websites. Nearly three quarters of the libraries offer credit courses, such as Information Retrieval and Database Search \& Use to undergraduate and/or graduate students. Some of them are required courses and others are electives. 


\section{Subject services}

As indicated in Sections 1.3 and 3.3 in this paper, over $60 \%$ of the libraries offer subject services. However, its development is uneven among the libraries. For example, the top three universities, Tsinghua University, Peking University and the University of Science and Technology of China, are different from one another as follows:

- Tsinghua University established advanced subject pages for different faculties using LibGuides and most of these pages are updated regularly.

- Peking University Library has thirteen subject blogs and most of the blogs are not up-todate. For example, the latest post on the Mathematics subject blog is dated 09-27-2013, which is over three years ago.

- The University of Science and Technology of China merely mentions the subject service in the About the Library section and does not have a webpage introducing the service or any subject librarian.

\section{Other Services}

This section includes: institutional repositories, data services and services unique to Chinese academic libraries.

\section{Institutional repositories and data services}

Five universities have institutional repositories for their scholars, or other local resources. Two of them are in beta. One is currently under construction.

Peking University Library is the only library that has an open research data platform based on Dataverse for users to publish, track, discover, reuse, and reproduce data. None of the libraries mention geospatial data or GIS software. It looks like this area has not yet been introduced into the Chinese academic libraries.

\section{Unique services}

Except Minzu University of China, all other institutions offered novelty search, research assessment, or citation and impact reports. This kind of service is unique to Chinese academic libraries.

According to Li (2007), novelty search is a kind of special information consultation provided by trained and certified librarians. Researchers are required to request a novelty evaluation report if they want to apply their "research ideas, research findings or a patent to practical use" (p. 145). The intention of this service is to prevent duplication of research efforts and support research in science and technology in China. University libraries have become the center of the science and technology novelty search service; and this "has been a significant advance" in China (p. 148). However, Johnson et al. (2010) argue that librarians may not have sufficient knowledge to assess research in some highly-specialized areas, and librarians' roles in American libraries "is assistive and advisory rather than evaluative" (p. 191). No matter how valuable these services are to the scientific research community in China, they seem more applicable to faculty rather than students. 


\section{CONCLUSION}

The results of this web survey indicate that certain services reported as challenges to Chinese students in Canada and other Western countries by previous studies, such as ILL, document delivery, reference services, and library instructions are now popular at the Project 985 university libraries in China. Open stacks, requests, OPAC, online databases as well as discovery layers and mobile services, are common in these libraries as well. However, course reserves, subject services, and off-campus access to electronic resources are not yet well established. Institutional repositories and data services are still rare in Chinese academic libraries. The findings have implications for Canadian academic libraries to improve their services to Chinese students. Libraries may design library sessions specifically for these students; or revise existing sessions accordingly. Library sessions targeting Chinese students may focus more on: off-campus access to library resources, course reserves, subject librarians, institutional repositories and data services.

\section{Acknowledgements}

The author would like to gratefully acknowledge Julia Zhuoran Zheng at McGill University for her help in proofreading this paper.

\section{References}

Beihang University. (2016). Jin Ri Bei Hang [Today's Beihang]. Retrieved from http://www.buaa.edu.cn/bhgk/jrbh/jrbh/index.htm

Canadian Bureau for International Education. (2016). Facts and figures: Canada's performance and potential in international education 2015. Retrieved from http://www.cbie.ca/about-ie/facts-and-figures/

Citizenship and Immigration Canada [CIC]. (2006). Facts and figures 2005 - Immigration overview: permanent and temporary residents, Canada - December 1 stock of foreign students by top source countries. Retrieved from http://publications.gc.ca/collections/Collection/Ci1-8-2005E.pdf

Citizenship and Immigration Canada [CIC]. (2015). Facts and figures 2014 - Immigrant overview: temporary residents - International students with a valid permit on December 31 st by top 50 countries of citizenship, 2005 to 2014. Retrieved from http://www.cic.gc.ca/english/pdf/2014-Facts-Figures-Temporary.pdf

Datig, I. (2014). What is a library? International college students' perceptions of libraries. The Journal of Academic Librarianship, 40(3-4), 350-356.

Guo, J., Huang, Q., \& Lu, X. (2014). Design and implementation of a subject librarian training program for university libraries in China. Reference \& User Services Quarterly, 54(2), 43-51.

Howze, P. C. \& Moore, D. M. (2003). Measuring international students' understanding of concepts related to the use of library-based technology. Research Strategies, 19, 57-74.

Jackson, P. A. (2005). Incoming international students and the library: A survey. Reference Services Review, 33(2), 197-209.

Johnson, M., Shi, W., \& Shao, X. (2010). Exploring library service models at Fudan University and Appalachian State University: Experiences from an international librarian exchange program. The International Information \& Library Review, 42, 186-194.

Kim, S. U. \& Shumaker, D. (2015). Student, librarian, and instructor perceptions of information literacy instruction and skills in a first year experience program: A case study. Journal of Academic Librarianship, 41(4), 449-456.

Li, A. (2007). A kind of transformation of information service - science and technology novelty search in Chinese university libraries. The Journal of Academic Librarianship, 33(1), 144-148.

Li, J., \& Yang, X. (2016). Current situation and countermeasures of copyright notice of the "Project 211" university library website. Library Research, 2016(2), 40-45 (In Chinese). 
Liao, J. (2004). A historical perspective: The root cause for the underdevelopment of user services in Chinese academic libraries. The Journal of Academic Librarianship, 30(2), 109-115.

Liao, Y., Finn, M., \& Lu, J. (2007). Information-seeking behavior of international graduate students vs. American graduate students: A user study at Virginia Tech 2005. College \& Research Libraries 68 (1), 5-25.

Liu, G. \& Winn, D. (2009). Chinese graduate students and the Canadian academic library: A user study at the University of Windsor. Journal of Academic Librarianship, 35(6), 565-573.

Ministry of Education of the People's Republic of China. (2008). "211 Gong Cheng” Jian Jie [About Project 211]. Retrieved from http://www.moe.gov.cn/s78/A22/xwb_left/moe_843/moe_846/tnull_33122.html

Ministry of Education of the People's Republic of China. (2011). “985 Gong Cheng” Jian Jie [About Project 985]. Retrieved from http://www.moe.edu.cn/publicfiles/business/htmlfiles/moe/s6183/201112/128828.html

Ministry of Education of the People's Republic of China. (2015). Educational Statistics in 2014: Basic Situation of the Region - Number of Higher Education Institutions. Retrieved from http://en.moe.gov.cn/Resources/Statistics/edu_stat_2014/2014_en02/201508/t20150831_204482.html

Morrissey, R. \& Given, L. M. (2006). International students and the academic library: A case study. Canadian Journal of Information and Library Science, 30(3/4), 221-239.

Peking University Library. (n. d.). Gai Kuang Yu Li Shi [General Information and History]. Retrieved from http://www.lib.pku.edu.cn/portal/bggk/bgjs/lishiyange

Shao, X., Scherlen, A., Johnson, M., Xu, X., \& Hu, Y. (2013). Chinese students in American academic libraries: A survey of Chinese user satisfaction with US library experience. International Information and Library Review, 45(1), 28-36.

Shen, Y. (2006). Chinese academic librarianship in transition: A comparative study between China and the United States. The International information \& Library Review, 38, 89-100.

$\mathrm{Su}, \mathrm{Q}$. (2016). The investigation on 211 project university library annual reports and its implication. Research on Library Science, 2016 (3), 11- 14 (In Chinese).

Tang, Y. \& Xia, Z. (2010). A study of subject service in Chinese academic libraries. CALA Occasional Paper Series, 7 , 1-6. Retrieved from http://www.cala-web.org/files/ops/OPSNov2010No7.pdf.

Wang, B. X. (2006). Academic library services to Chinese international students in New Zealand (Master's thesis). Retrieved from http://www.nzcer.org.nz/system/files/T01025.pdf

Wang, H., Niu, G. \& Hubbard, W. J. (2004). Current status of reference services in academic libraries in mainland China: A web analysis. The International Information \& Library Review, 36, 105-110.

Xie, J. \& Sun, L. (2015). Exploring Chinese students' perspective on reference services at Chinese Academic libraries: A case study approach. The Journal of Academic Librarianship, 41(3), 228-235.

Yao, Y., Liao, Y., \& Wang, H. (2015). Current situation of freshmen column in "985 Project" academic libraries. Chinese Journal of Medical Library Information Science, 24(3), 71-74\&79 (In Chinese).

Zhao, J., \& Mawhinney, T. (2015). Comparison of native Chinese-speaking and native English-speaking engineering students' information literacy challenges. Journal of Academic Librarianship, 41(6), 712-724. 


\section{Appendix: Project 985 Universities}

\begin{tabular}{|c|c|}
\hline University & Library Website URL \\
\hline Peking University & http://www.lib.pku.edu.cn/portal/ \\
\hline Tsinghua University & http://lib.tsinghua.edu.cn/dra/ \\
\hline University of Science and Technology of China & http://lib.ustc.edu.cn/ \\
\hline Nanjing University & http://lib.nju.edu.cn/html/index.html \\
\hline Fudan University & http://www.library.fudan.edu.cn/main/index.htm \\
\hline Shanghai Jiao Tong University & http://www.lib.sjtu.edu.cn/ \\
\hline Xi'an Jiaotong University & http://www.lib.xjtu.edu.cn/ \\
\hline Zhejiang University & http://libweb.zju.edu.cn/libweb/ \\
\hline Harbin Institute of Technology & http://www.lib.hit.edu.cn/ \\
\hline Beijing Institute of Technology & http://lib.bit.edu.cn/ \\
\hline Nankai University & http://www.lib.nankai.edu.cn/ \\
\hline Tianjin University & http://www.lib.tju.edu.cn/ \\
\hline Southeast University & http://www.lib.seu.edu.cn/ \\
\hline Wuhan University & http://www.lib.whu.edu.cn/web/default.asp \\
\hline Huazhong University of Science and Technology & http://www.lib.hust.edu.cn/ \\
\hline Jilin University & http://lib.jlu.edu.cn/portal/index.aspx \\
\hline Xiamen University & http://library.xmu.edu.cn/portal/\#\&panel1-1 \\
\hline Shangdong University & http://www.lib.sdu.edu.cn/portal/tpl/home/index \\
\hline Ocean University of China & http://library.ouc.edu.cn/ \\
\hline Hunan University & http://lib.hnu.cn/ \\
\hline Central South University & http://lib.csu.edu.cn/pubnew/zndxtsgnew/index.html \\
\hline Dalian University of Technology & $\begin{array}{l}\text { http://www.lib.dlut.edu.cn/; } \\
\text { http://wwwd.dlut.edu.cn/ (new, in beta) }\end{array}$ \\
\hline Beihang University & http://lib.buaa.edu.cn/ \\
\hline Chongqing University & http://lib.cqu.edu.cn/newversion/index.htm \\
\hline Sichuan University & http://lib.scu.edu.cn/ \\
\hline University of Electronic Science and Technology of China & http://www.lib.uestc.edu.cn/ \\
\hline Sun Yat-Sen University & http://library.sysu.edu.cn/ \\
\hline South China University of Technology & http://www.lib.scut.edu.cn/ \\
\hline Lanzhou University & http://lib.lzu.edu.cn/ \\
\hline Northwestern Polytechnical University & http://tushuguan.nwpu.edu.cn/ \\
\hline Northeastern University & http://202.118.8.4/ \\
\hline Tongji University & http://www.lib.tongji.edu.cn/ \\
\hline Beijing Normal University & http://www.lib.bnu.edu.cn/ \\
\hline Remin University of China & http://www.lib.ruc.edu.cn/ \\
\hline
\end{tabular}




\begin{tabular}{|l|l|}
\hline University & Library Website URL \\
\hline China Agricultural University & http://www.lib.cau.edu.cn/ \\
\hline National University of Defense Technology & http://library.nudt.edu.cn/ \\
\hline Minzu University of China & http://www.lib.muc.edu.cn/cn/Home/ \\
\hline East China Normal University & http://www.lib.ecnu.edu.cn/ \\
\hline Northwest A\&F University & http://lib.nwsuaf.edu.cn/ \\
\hline
\end{tabular}

\section{About the author}

Guoying Liu is Librarian, Head of Systems at Leddy Library, University of Windsor. Her research interests include library technology, electronic resources management, and library services to international students. She has conducted grant-supported research projects on information literacy and international students. 